\begin{tabular}{r}
\hline \\
$821.163 .41 .09: 398$ \\
$398(=163.41): 94(367)$ \\
https://doi.org/10.18485/mks_srpska_slavistika.2018.2.ch28
\end{tabular}

Снежана Д. САМАРЏИЈА*

Универзитет у Београду

Филолошки факултет

Катедра за српску књижевност са

јужнословенским књижевностима

\title{
СЛОВЕНСКИ СВЕТ У СРПСКОМ УСМЕНОМ СТВАРАЛАШТВУ**
}

\begin{abstract}
Различити поступци стилизације и значења везана за Словене заступљени су у српскот фолклору, нарочито међу епским песмама. Овом приликом се издвајају поједини ликови (Шишман, краљ Владислав, московски/руски владари); њихови односи са јунацима српске традиције и маркирања простора. Уз корпус песама „на народну”, назначен је шири контекст сусрета словенских култура.

Кључне речи: Словени, српско усмено стваралаштво, ликови, формула, простор.
\end{abstract}

Представе о другим народима и у српском фолклору првенствено зависе од поетичких законитости усмених облика. За апстрактни стил бајке није пресудно чији су царски синови и кћери, нити се препреке на њиховом путу иницијације географски одређују. Међу легендама и предањима преовлађују веровања о богу, свецима и демонима или тумачења настанка и нестанка видљивог и познатог окружења. Остале приповедне форме ${ }^{1}$ махом одражавају породичне и друштвене реалије одређене средине. Лирске народне песме и лирско-епске врсте усмерене су на свакодневни живот, древни и христијанизован аграрни календар (Meletinski, b. g.), обреде прелаза (Ван Генеп 2005), биолошке и емотивне промене, битне за јединку и патријархалну задругу. Тек по изузетку, спомињу се „странци”, што илуструје обредна минијатура о древном богу светлости. Његово одсуство током зимског периода изједначено је са ратним походом:

*markosoft91@gmail.com

** Рад је део пројекта Српско усмено стваракаштво у интеркултурном коду (Институт за књижевност и уметност у Београду), који финансира Министарство РС.

${ }^{1}$ Басне, приче о животињама, шаљиве приповетке, новеле, анегдоте. 


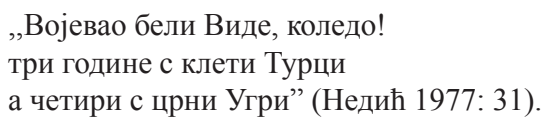

Искуство заједнице пресудно је и за епску слику о суседима и далеком свету (Млеци, Угари, Турци, Арапи), било да се активирају ритуално-магијски слојеви баштине, митске представе и/или рефлекси историјских реалија. Сходно техници грађења ликова, пријатељи и непријатељи се именују и по територији којој припадају: од Немаца бан, Муса Арбанаса и Ђемо Брђанин, Филип Маџарин, од Хорвата Мато, Грчић Манојло. Наспрам мање-више персонализованих актера, колективни и споредни ликови одређују се по просторно-етничкој „припадности” (угарска господа, Латини, Арапија). Те црте повезане су и са друштвеним статусом: млетачки дужд, угарски краљ; турски султан, мада се он одређује и као цар Мурат, Бајазит, Појазит, Отмановић. Ознака ,туђег” света не носи увек негативан предзнак. Карактеризација зависи од односа тих актера према главном (,ннашем”) протагонисти и усклађена је са сижејним моделом.

У српској епици се спомињу и словенски народи. Неоспорно, током бурне историје Словена на Балкану избледеле су успомене на прасловенску заједницу, мада се везе слуте из дубинских слојева традиције. ${ }^{2}$

\section{У онога цара Шишманина}

Међу најстаријим записима и у грађи коју су сакупили Вук Караџић, његови савременици и следбеници, поједина имена и локалитети се посредно или директно односе на друге Словене. Од суседа, са којима су успостављани различити контакти, изгледа да се памтила бугарска династија Шишмана.

Једна од најраније записаних балада ${ }^{3}$ обликована је као дијалог између девојке и Шишмана (Милошевић-Ђорђевић 1986: 139-148; Пантић 2002: 59). Тај Шишман, додуше, не носи ниједну од средњовековних владарских титула. Има тек улогу гласника, док извештава о исходу неке битке између хришћана и Турака. Забринута за судбину краљевића Андријаша и Лазара, анонимна девојка баш од Шишмана очекује да ће чути поуздане гласове. Сцена дијалога је оквир ретроспективног сведочења о витешком држању заробљених јунака. За естетске домете ове баладе и значење опеваног удеса није пресудна историјска подлога, мада су проучаваоци у личним именима ликова налазили рефлексе историјских збивања на Балкану из друге половине 14. века.

И једна варијанта из Вукове збирке може, али и не мора бити одјек успомена на средњовековне сукобе Срба са Бугарима. Владари зараћених страна - српски цар Стеван и бугарски краљ Мијајло су споредни ликови (Караџић 1988: 31). Редуковано се приказује њихов двобој, што није честа епска сцена, јер се иначе огледају

\footnotetext{
${ }^{2}$ Те се везе указују у истраживањима словенског фолклора (Халански 1894; Толстој 1995; Веселовски 2005: 601-650; Гура 2005 итд.).

${ }^{3}$ Петар Хекторовић је слушао баладу 1555/1556. од двојице рибара и, заједно са три лирске почаснице и две бугарштице, унео у Рибање и рибарско приговарање (Венеција, 1568).
} 
заточници. Али рат две државе само је део спољашње мотивације за удаљавање главног јунака из свога дома и варијацију модела о неверству жене (Меденица 1965, Krstić 1984: 183-185). При тумачењима ове песме такође су уочаване историјске секвенце, колико год да су оне суштински безначајне за карактеризацију ликова и (типичну) породичну драму. Ипак, делећи мишљење Д. Костића, С. Матић сматра да је судар две војске рефлекс битке код Велбужда из 1330. када је погинуо бугарски цар Михајло Асен III Шишман. Истиче и да је Михајло „обично име краља странца, али овде се то име стварно поклопило са историјским краљем бугарским који је ратовао са Дечанским” (Матић 1958: 673-674).

Сукоби између Немањића и Шишмана иначе су решени тако што је сестра Јована Александра, Јелена, постала жена цара Душана. Премда се епски цар Стјепан жени странкињом, те епске околности немају историјских примеса, већ су стилизоване према класичном моделу (Реšić - Milošević-Đorđević 1984: 112-113; Петковић 2008: 16-45).

Али, познатог јунака балканских простора опчини девојка коју види:

„А под двором краља Шишманина, Мати моја у земљи Бугарској” (Вук II: 56º).

У овој обради јуначке женидбе са препрекама, тазбина је благонаклона према зету, те краљ Шишманин саветује Марка да из сватова изостану странци.

Бугарски владар се у другој песми прецизније одређује:

„Од Трнова од земље Бугарске” (Караџић 1988а: 75²).

Своје зле намере да погуби кума Радул-бега, притворни Шишманин плаћа главом. Историјски догађаји имали су другачији ток, јер се Шишман умешао у спор око престола између браће Мирче и Дана. Коментаришући споне историје са епиком и анахронизме, Матић указује на процесе стилизације. Конкретни догађаји су „добили у нашој песми облик романтичне приповетке о завади међу браћом” (Матић 1958: 739).

Т. Маретић у лику Шишмана препознаје последњег бугарског цара Јована Шишмана III, после чије смрти бугарско царство нестаје под окриљем турске империје Такође примећује да је бугарски цар, по историјским подацима и епским песмама, савременик краља Марка Мрњавчевића и влашког војводе Радула (Maretić 1966: 230).

Колико год да су српско-бугарске везе биле непосредне и динамичне, успомене на средњовековну прошлост подређене су епској техници. Народ и територија су апстраховани ликом владара, којем независно од карактеризације и сижејне окоснице увек припада споредна улога.

\section{Ово му је сврха била славна краља Владислава}

Када се у старијим записима спомиње краљ Владислав, титула владара Угарске потпуно апсорбује краљево порекло. Изостају чак и алузије на пољско-литавску династију Јагелона (Јагелонаца, Јагеловића), чији је краљ Владислав III, као Владислав 
I, био на челу Угарске од 1440. до 1444. Његова погибија код Варне, у бици између угарских и пољских снага против султана Мурата II, стопила се са епском традицијом о Косовском боју из 1448. Поразе хришћана повезао је и Јанош Хуњади - епски Сибињанин Јанко. Сходно епском делокругу владара (Самарџија 2008: 201-241), Владислав је пасиван, док се са историјским појединостима подудара тек младост епског краља, чије је име током векова заборављено. ${ }^{4}$ Иако се опевају покрет трупа и трагичан исход окршаја, радња је удаљена од обе битке (на Варни и Косову), а мотиви се више групишу око породичних односа него што укључују јавно делање војсковође. ${ }^{5}$

Име Владислава краља среће се и међу лирским песмама Ерлангенског руко$n и с a$, али је уз владарско достојанство наглашена старост јунака - као непожељног мужа (Геземан 1925: 48º. И друга, лирско-епска варијанта је удаљена од историје (Геземан 1925: 49). Када сина кнеза Владислава заробе Турци, отац тражи да га погубе, како не би био сведок смрти свога јединца. ${ }^{6}$

У бугарштицама краљ Владислав гине без наследника, остављајући мајку и неудату сестру да туже за њим. Трагичан исход боја увећава се и као коб породице. Премда су овакве околности универзалне при описима ратних сукоба са разних простора, можда би се могле повезати са нестанком лозе Јагелонаца након Мохачке битке из 1526, када гине последњи изданак куће, Лајош II. Међутим, епске реминисценције су ишле другим смером. Док се пораз хришћана код Варне „замењује” њиховим страдањем на Косовом пољу, локалитет Мохачке битке се боље очувао:

$$
\text { „Турци војску разбише на л’јепому Мухачеву” (Богишић 1878: 24º). }
$$

По типичном епском анахронизму и на овом бојном пољу налази се Угрин Јанко војвода, али се име краља не спомиње.

\section{Москови су од боја јунаци}

Међу записима са српско-хрватског језичког простора од краја 15. до половине 18. века само се једном спомиње Петар од Москова (Богишић 1878: $116^{\circ}$ ). Придружен је каталогу ратне коалиције, обликоване по принципу формуле о „седам краљевина", а борбе се воде против везира Али-паше како би се освојио Београд. Хришћанске трупе предводи од Беча чесар, принцип Алесандро. Петрова титула изостаје, али се он према ћесару опходи као једнак у хијерархији, јер му:

${ }^{4}$ И Други косовски бој и удес краља Владислава опевани су међу бугарштицама, док су за Вукове певаче били занимљиви тек поједини мотиви везани за Јанка и Секулу (Караџић 1988a: $81^{\circ}, 85^{\circ}, 86^{\circ}$; Караџић 1988б: $\left.30^{\circ}\right)$.

${ }^{5}$ Слични мотиви, уз адекватну измену номенклатуре ликова, укључени су у епско приказивање Првог и Другог косовског боја (веридба уочи боја, сновиђења, извештаји са попришта, оплакивање погинулих, препознавање убијеног јунака по прстену итд. Богишић $\left.1878: 1^{\circ}, 2^{\circ}, 19^{\circ}-22^{\circ}, 25^{\circ}, 28^{\circ}, 2^{\circ}\right)$. Мотивска сродност стилизације ових историјских догађаја подстицала је проучаваоце на различита тумачења путева генезе тематских кругова српске епике (Костић 1939; Михаљчић 1975; Петровић 2001).

${ }^{6}$ Иначе, ово није усамљен пример да се историјске личности, опеване у епској поезији, именују као ликови лирских и лирско-епских песама.

${ }^{7}$ Каталог чине: Текелија Јово, Ракоција краљ пољашки „од Полашке равне”; Петар од Москова, Вишњица краљица и њен зет Јован/Дука „од Горанце”, у чијој су војсци Хрвати. 
„не целива руку ни кољена,

Нег’ чесара у бијело лице”.

Ова хроничарска обрада започиње класичном формулом вилиног кликовања, а укључују се и други мотиви карактеристични за епску стилизацију бојева (нпр. ухођење непријатеља) или хајдучких акција (нпр. деоба плена). Петру од Москова поверено је старање о војсци, распоред трупа и утврђивање броја погинулих.

Наспрам старијег корпуса грађе, у десетерачким песмама из збирки Вука Караџића, његових савременика и следбеника, спомињу се московски краљ/цар, госпа Јелисавка, московска краљица/царица. Када су варијанте састављене по узору на усмену епику (певање „на народну”), предочавају се прецизне титуле или мала генеалогија царских породица. Оба типа именовања не подразумевају само владара одређене области него активирају још једну, битну компоненту значења. Московски краљ често и није присутан на епској сцени или је, попут московске царице, најављен уводном формулом, али певани догађаји истичу повезаност Срба и Црногораца са „Московима”.

Илузија епске објективности (и поузданог казивања) ослања се на подразумевање просторне удаљености. То не умањује узајамно пружање војне помоћи у даљој и блиској прошлости. Певачи и писци епских стихова опевају разне руско-турске ратове, док су јасно датирани поднаслови песма из пера црногорских. Таква знања су уско омеђена личним искуством, било да су појединци обавештени о европским збивањима, да су путовали до Русије, или су примали руске дипломате упућиване ка Црној Гори и српској држави у зачетку. ${ }^{8}$

Једна песма9 из Вукових антологија приближава Московску српској средњовековној држави. Вариран је мотив о девојци коју проси више јунака, ${ }^{10}$ али удаја Јеринине кћери и њени просци подређују се фолклорним „тумачењима” српске историје. Поред московског краља, истом девојком намеравају да се ожене Вилип Маџарин и цар Отмановић. Ликови се разликују по друштвеном положају (феудални велможа - краљ - цар) и, још изразитије по верској припадности - католицима, православној цркви и исламу. Избором султана за зета, Јерина решава судбину српске деспотовине:

„Даде ћерку за Отмановића

И с њом даде земљу и градове” (Караџић 1988а: 80).

Кроз удес српске принцезе и пад Смедерева преплетени су мотиви и формуле са честицама историје. ${ }^{11}$ Спомињање других просаца само појачава кривицу Ђурђеве Јерине и један је од разлога с којих јој припада епитет - проклета.

\footnotetext{
${ }^{8}$ Историјат веза Србије и Русије неће овом приликом бити разматран, јер је то посебна и велика истраживачка област, јер се контакти, у оба правца, могу пратити од средњовековне епохе до 21. века.

${ }^{9}$ По Вуковој напомени, певач ове песме, Павле Ирић, „служио [jе] као момак у књаза Милоша” (Недић 1981 65-66; Караџић 1986: 402). Самим тим, могао се лакше од других певача упознати са разним иностраним везама.

${ }^{10}$ Овај чест модел женидбе-удаје (Krstić 1984: 256-257) реализује се на више начина, уз срећан или трагичан исход свадбе, уз поштовање невестине жеље или одлуке старешине куће.

${ }^{11}$ Петнаестогодишња Мара Бранковић дата је 1433. у харем Мурата II. А, када су кључеви престонице предати Турцима 1459. са мапе Европе нестаје српска деспотовина. Два догађаја из средњовековне историје предочена су у епској песми као узрок и последица.
} 
Другачије су предочени рефлекси историјских сукоба Турске са Русијом. Размена дарова истиче ,,разлоге” опадања и успона царевина, а главна улога припада - старом српском патријарху. Његова мудрост и спремност на жртвовање пресудни су за односе снага две велесиле. Он зна тајну хришћанских реликвија и саветује султана:

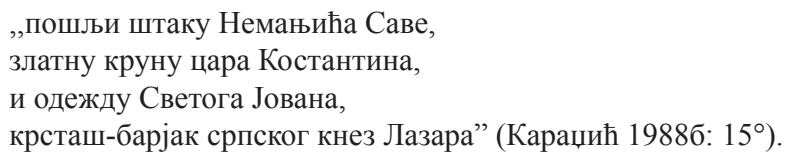

Султан не слути значај тих предмета. Лојалан саветодавац, паша Соколовић, прекасно открива господару да су та знамења давала моћ турској царевини.

Од четири симбола православља, два су истовремено српске светиње из периода успона и краха средњовековне државе. Тако је у епском систему очуван смисао веза Русије и Србије, уз преокренуте позиције заштитника и оних којима је помоћ потребна. Иницијална формула ове песме је јединствена варијација учесталих епских увода (Детелић 1996: 140). У магловитој представи о локалитетима, изједначава се име престонице са целом територијом „Москве простране”. Можда и због природе заплета, али и због непознавања историје, епизодни лик Мехмед-паше Соколовића је негативно окарактерисан. ${ }^{12}$ J. Деретић овој песми даје посебно место:

„Песме на стране теме не образују посебан тематски круг, оне се могу узети као интернационални историјски оквир за песме 'средњих времена'. За идеологију песама 'средњих времена' највећи значај имају песме у којима се Русија ('Московија') представља као највећа хришћанска сила и заштитница поробљених балканских хришћана" (Деретић 2000: 270-271).

По Вуковом сведочењу те су теме живеле у више варијаната. Драгоцено је његово запажање да су некад: ,узета лица готово из данашњега нараштаја.”13 Уношење нових имена у старије обрасце је уобичајен поступак епске стилизације. Али, напоредо са анахронизмима уочава се и процес реверзибилности, када називи из старијих епоха истискују млађа именовања појединих територија, држава, градова и владара. То се одлично испољава при везивању епске радње и ликова за Московију. ${ }^{14}$ Поред старијег имена, честе су и алтернације (Московија и Русија), док у певању на народну преовлађује означавање - Русије.

\footnotetext{
${ }^{12}$ Банашевић изричито тврди како певач „није знао да је Соколовић био наклоњен Србима и да је баш његовом заслугом обновљена Пећка патријаршија (1557. године)" (Банашевић 1954: 599).

${ }^{13}$ У напомени је сажет сиже о писмима госпе Јелисавке, која најпре од султана Сулејмана, а затим од цара Татарина, тражи да јој врате реликвије. Пошто Татарин прети како ће: „војску на њу подићи Петрибора с земљом поравнити” започне рат „и Госпа Јелисавка завлада Крмом” (Караџић 1954: 88-89). Каталог реликвија се у више варијаната постојано чува, уз незнатна варирања:

,Златна круна цара Симеуна/ И одежда Светога Јована,/ Крстат барјак цара Константина,/ Златна штака светог оца Саве,/ Бритка сабља силнога Стефана/ И икона оца Димитрија” (Караџић 1974/IV: $2^{\circ}$ ).

Заплет је исти и када се каталог редукује на три света предмета, али се у таквом контексту кратко евоцирају важни догађаји, попут Косовске битке или пада Цариграда. (Караџић 1974/IV: $3^{\circ}$ ).

${ }^{14}$ Велику московску кнежевину је од 1547. наследило Руско царство, на челу са царем, а од 1721. императором Петром Великим.
} 
Још две песме из Вукових „средњих” епских времена посвећене су руско-турским сукобима и променама ратне среће. Из перспективе хришћанских певача предочене су победе госпе Јелисавке над Бећир-пашом. Светећи браћу и очевину, Црнојевић Саво погуби пашу, а на молбу московске господе поштеди живот пашином сину. Млади Осман-бег прима православље и покалуђери се. Догађаји се нижу ретроспективно, помоћу устаљеног оквира о гаврановима, након чијег извештаја умире љуба пораженог јунака (Караџић 1988б: 88). У другој песми колективни лик победника представља „русиску господу”. Они од заробљеног Хасан-паше желе да сазнају какви су градови, јунаци и девојке по Босни и Херцеговини (Караџић 1988б: 89$)$.

Састављајући напомене уз ове варијанте, Н. Банашевић с правом сматра да последња песма нема историјска упоришта. Дијалог између Хасан-паше и капетана Влајсављевић Јове само треба да увелича добра утврђења Фоче и лепоту Фочанки. С друге стране, Банашевић је истакао историјску подлогу песме Бошъаци на Москову. Он примећује да се епска Озија може препознати као варош Очаков близу Одесе, где су Турци више пута били поражени, упркос утврђењу Озу-Кале (Банашевић 1954: 694).

Песма о руско-турском сукобу, коју је Вук 1830. записао од слепог гуслара Гаје Балаћа (Караџић 1986а: 399-400), није естетски успела. Међутим, она потврђује колико је ова тема привлачила пажњу различитих певача, уз постојано чување локалитета Озије „испод Московије” (Меденица 1975: 393-395). Једну од тих варијаната Сарајлији је певао слепи гуслар Гашо Ришљанин, чији репертоар садржи неколико песама о руско-турским сукобима (Милутиновић $1990: 165^{\circ}, 166^{\circ}, 167^{\circ}$ ).

При опевању узећа Озије ликови се доследно одређују као Москови и „удовица московска царица". Локализација радње и јунака из песме Морски бој Русах с Typцима је другачија: Орле је „руски ђенерал”, „од Русије земље православне”, а његова узданица Лесо је „словинскога рода и племена”. Трећи запис је варијација честог модела спасавања градова од зулума црног Арапина. Мемед-Арапин удара уобичајене намете Московији - „под стојнијем Петробургом градом”. Гуслар користи оба назива Русија славна и Московија, док је заточник ,русинске царице” Иво из Подгорице. Наспрам дугог путовања, од Земуна, преко Беча до „русинског” двора, мегдан је веома сведен. А када Иво ослободи „,русинске / Московке ђевојке”, царица му дарује: „колаину од сувога злата,/ што јунаци носе око врата”.

Овакав вид указивања почасти заслужним јунацима могао би се везати за различите историјске периоде. Међутим, животне реалије певача и слушалаца спонтано активирају процесе реверзибилности. Песме „спеване” у 19. веку показују колико је за карактеризацију и главних и споредних ликова пресудан удео публике пред којом песма настаје. Православним певачима и слушаоцима су Московија - Русија и њени владари моћни заштитници, чије победе и помоћ могу да воде до ослобођења из вековног ропства. Међу Муслиманима је, напротив, Русија вечити непријатељ, који на разне начине угрожава највиђеније породице.

Учешће српских трупа у руским војним походима само је позадински мотив казивања о деспоту Стефану Лазаревићу (Милошевић-Ђорђевић 2011: 222-223). Последње деценије српске средњовековне државе се подразумевају именовањем владара, у чију се поетску биографију укључују различито мотивисана путовања. По предању: „Високи Стефан идући с војском из Московске у Србију дође у Будим на конак [...]” (Караџић 
1969: 187). Околности су битне само због тумачења рођења војводе Јанка. ${ }^{15}$ За приповедача (и публику) није пресудно због чега деспот Стефан борави баш у Московској. Али детаљи из варијаната с краја 19. века посвећени су и тим разлозима.

\section{„Русинско царство” у певању на народну}

Записи Богољуба Петрановића, као и песме црногорских владара-песника илуструју прелазни тип епске стилизације, у којој се наслеђен фонд формула повезује са афинитетима и циљевима писмених аутора епских варијаната. Но, и поред измењеног процеса настанка текста, овакве писане творевине испољавају извесну подударност са аутентичним усменим фондом. Додири су изразити на стилско-изражајном нивоу, а понекад је уочљива и мотивска сродност са старијим слојем епског певања. Фабуларну окосницу Петрановићевих песама о деспоту Стефану и Змај Огњеном Вуку чини рођење или детињство најмлађег изданка владарске лозе. Дете мора бити склоњено из родитељског дома и отаџбине, јер му о глави ради узурпатор престола. Због издаје проклете Јерине, њеног унука (Геземан $1925: 21^{\circ}$ ) родитељи поверавају угарском краљу. Такав сегмент Вукове епске биографије подразумева се и међу бугарштицама. ${ }^{16}$

По записима из Петрановићеве збирке другачије су одређени уточиште и страни владар, заштитник. „Госпојица русијска краљица” чува Змаја Огњеног од злонамерне Јерине и Турака (Петрановић 1867/II: 40). Сличне је судбине и његов ујак Високи Стеван, јер га је мати: „малена [...] у Русију дала” (Петрановић 1870: 29²). Околности изгнанства су различити. Осим заштите од Вука Бранковића (Петрановић 1867/II: $29^{\circ} ; 1870: 21^{\circ}$ ), истиче се образовање деспота, јер га у Русију шаљу:„Да научи велике науке / књиге и науке" (Петрановић 1867/II: 28; 1870: 22). Руски владари се кроз варијанте мењају (Алексије краљ, русијска краљица), али је чврста веза између њих и српског јунака, мада штићеник мора да прође иницијацијски тест. ${ }^{17}$ И Владика Петар I шаље синовца Рада „цару русинскоме” (Караџић 1974/IV: 30).

Из епског корпуса, бележеног током 19. века, могао би се издвојити мали круг „руских” тема. У тим песмама се смењују руски цареви (Павле, Николај, Алесан-

\footnotetext{
${ }^{15}$ Изразита је подударност Вуковог предања са бугарштицом о рођењу сибињских близанаца (Богишић $1878: 8^{\circ}$ ). Ово није усамљен пример адопције странца у националну баштину (Самарџија 2014). Кроз тумачење порекла Сибињанин Јанка испољава се и типичан процес инверзије узрока и последица при обликовању колективног „знања” о прошлим епохама. Сличне „народне историјске традиције” плету се око свих значајних догађаја и многих личности (Новаковић 1982: 4-14), често у потпуном раскораку са историјским чињеницама.

${ }^{16}$ Јерина издаје Турцима тек рођеног унука, јер се по његовим обележјима види да ће бити велики јунак. У овој варијанти те одлике су ближе особинама чудесне, златне (прогоњене) деце из бајке, која по правилу постају жртве бабе, тетке, очеве маћехе итд. Сличан мотив, усклађен са епском стилизацијом, везује се за Змај Огњеног Вука. Варијанте: Милутиновић 1990: 152; Караџић 1975: 735; Караџић 1988а: 12; Караџић 1966: 236 и Караџић 1986б: 308-309 (Змајогњени); Krstić 1984: 262. У песми о аманету Змај Огњеног Вука, јунак - вазал наглашава оданост господару. Мада се не наводи којом земљом влада тај краљ, служење Угарској је заједничка појединост низа бугарштица, а порука укључује дуг временски период Вукове оданости: „Вјерно сам те дворио од дјетета малахнога, / Од дјетета малахнога до јунака великога" (Богишић 1878: 16²)

${ }^{17}$ Под утицајем модела бајке о спасиоцу царства, развија се епизода јунаковог двобоја против аждаје. У једној варијанти низ епизоде укључују и друге сегменте предања о судбини Високог Стефана
} 
дар, Петар), а опевани су махом ратови и мировни споразуми. Кроз догађај се понекад преламају судбине Србије и, нарочито, Црне Горе. Текстови се налазе међу Вуковим рукописима и у збиркама Симе Милутиновића, Његоша и Петрановића. Милутиновић уз запис из Пјеваније некада наводи, а понекад изоставља податак о ствараоцу ${ }^{18}$, док Његошево Огледало српско не садржи такве напомене. Ипак, најчешће се зна ко је аутор-писац стихова, а и када те белешке изостају јасно је да их није испевао неписмен гуслар. Доминира десетерац, мада има и осмерачког певања „на народну”, понекад са једноставном римом. Овај тип стилизације условно је близак усменим хроничарским моделима, од којих се разликује по тематици, наглашеној историчности, намени, начину стварања дела и по процесима његовог преношења. Писци су црногорске владике и владари, Петар I и Петар II Петровић Његош, док је сенка сумње у аутентичност грађе обележила Петрановићеве збирке.

Спомињу се у тим песмама султани, од „Беча ћесар”, Луј Бонапарта, Шведи, Угари, војска „Леа и Пољака”, међутим, само руски цареви имају посебну улогу избавитеља православних „Слављана” (Караџић 1974/IV: 38, 55). По узору на епске обраде бојева, предочене су битке из руско-турских ратова, учесталих током 18. и почетком 19. века, са променљивом ратном срећом. Прослављен удео руских савезника, односно црногорских јунака, открива и средину у којој се пева. Једно анегдотско сведочење Вука Врчевића, везано је баш за настанак песме о војевању царице Катарине II против турског цара. Наиме, млади Раде Томов је 1829. нашао књижицу о овом рату, на руском језику, и саставио је песму „у народном духу”, која је била толико популарна да се „по свој Црној Гори уз гусле пјевала” (Меденица 1975: 141).

На сложена питања стварања и трајања једног тока усмене епике први је указао Вук, поводом песама које су певали слепи гуслар Ђура Милутиновић и неки Црногорац. Вук примећује: „Ја за цијело мислим да је ове обадвије пјесме о боју Црногораца с Махмут пашом начинио црногорски владика Петар I (садашњи Свети Петар), па су послије ушле у народ и идући од уста до уста колико се могло догоњене према народнијем пјесмама" (Караџић 1986а: 66).

Механизам реверзибилности могао би се придружити својствима ауторског писања стихова по узору на усмену епику, нарочито ако написана варијанта започне и свој усмени живот. Друштвени статус епске песме у одређеним срединама био је погодан и за ширење политичких идеја, чији су заговорници владари и/или сакупљачи умотворина. Идеолошке тенденције ${ }^{19}$ обухватају и представу о Русији као великој заштитници православних народа, који се вековима боре за слободу, а одолевају исламизацији и унијаћењу. Процеси „спуштања” те идеологије из уског круга образованих људи ка најширим слојевима (још увек неписменог) пука никако се не могу генерализовати до теорије о постанку целокупне епике. Примери, заправо, одражавају тек једну, можда и завршну, етапу трајања епског песништва. Тај тип

\footnotetext{
${ }^{18}$ Име певача (или писца) изостаје (,ма не знам ким је спјевана” или „не знам од кога је имам”) уз део песама, чији су аутори Петра I Петровића и Његоша (Милутиновић 1990: 979), а међу њима су и обраде ,руских” тема.

${ }^{19} \mathrm{O}$ политичком концепту који чини шири оквир штампања збирки С. Милутиновића и Његоша в: Љубинковић 2000: 204-266.
} 
стилизације је континуирано пратио матични - усмени ток епског спевавања ${ }^{20}$, да би постао доминантан у постфолклорном периоду живота традиције. ${ }^{21}$

Ауторске песме о руско-турским ратовима прешле су пут од написаног текста до усмене импровизације, било да су их извођачи учили „наизуст” или су их „догонили" према општем фонду усменог наслеђа. С обзиром на то да је локализација увек битна компонента епске структуре, особен сигнал „страних” тема постају називи географских појмова. Имена далеких градова, река, поља и мора преузимају се аутоматски, уз варирања која одају певачево непознавање локалитета.

\section{Земље и градови Словена}

Осим алтернације Московске и Русије као синонима, певачи и њихови слушаоци оваквим ознакама одређују удаљене територије. Атрибуција понекад подразумева велико пространство, јер се за Моску, Москву, Московију и Московску везују епитети „равна” и ,пространа” (Detelić 2007: 277), ${ }^{22}$ премда су варијације придева „равна” учестала формула уз читав низ локалитета опеваних у епској песми са ових простора (Detelić 2007: 537-541). Некада се таква одредница подудара са рељефом, али је додавање епитета руковођено ритмом асиметричног десетерца.

Име Петрограда је преиначено, можда и под ,притиском” назива Санкт-Петербург. Певачи по свом поимању прилагођавају „значење” када спомињу Петарбур, Петребур, Петрибор, или Петробор. Као особени „дублети” јављају се и одреднице Крм и Крим, док се освајање Севастопоља „тврдог” опева у једној од ауторских песама (Караџић 1974: $38^{\circ}$ ). Кијев се спомиње као град, поље (Караџић 1974: $2^{\circ}$, $3^{\circ}$ ), али је и „висока планина” (Detelić 2007: 192).

У већем броју песама о руско-турским ратовима спомиње се Озија, односно име утврђења Озу-Кале, које је за поједине Вукове певаче „испод Московије” (Вук $3,88 ; 7,56)$. Код Милутиновића се међу песмама о ратовима Русије против Турске спомиње и Одеса, Одес (Милутиновић 1837: 46, 55). Другачија значења приписана су луци на левој обали Дона, при ушћу у Црно море. Варијације имена Азов, Азак и Хазак срећу се и међу ауторским хроникама о руско-турском рату. Али, далеки град означава опасно место у моделима о робовању епских јунака. По представама певача Азак припада оностраним сферама, те се успоставља аналогију између земље/краља арапског и азачког. Док је у азачкој тамници, Марко јавља побратиму како су „Тешке муке у арапске руке”, а спасилац се на путу ка Азаку прерушава: „Начини се црни Арапине” (Караџић 1988а: 65²).

Локализација је део епске технике, док фабуларно језгро сеже до аграрних митова (Meletinski b. g: 222-223). У старијој варијанти (Богишић 1878: $5^{\circ}$ ) и код Вука (Караџић 1988а: 64º), хтонска обележја су изједначена са јунаковим боравком ис-

\footnotetext{
${ }^{20}$ Сродном виду обрада може се придружити и део варијаната из збирке Б. Петрановића, због чега су проучаваоци сумњали у аутентичност овог корпуса.

${ }^{21}$ Међу особеностима оваквих епских хроника је, између осталог, мање-више наглашена идеолошка димензија. Аутори су писмени, те се по образовању разликују од претходних генерација гуслара. В: Ђорђевић Белић 2016.

${ }^{22}$ У корпусу словенске народне поезије за Москву се везује и епитет камена (Detelić, Ilić 2006: 220).
} 
под земље, где се налази тамница арапскога краља. Увођење Азака града са истим значењем које има арапска територија можда указује и на природу обавештености сељака из Рудничке нахије. Овај Вуков певач је и при стилизацији Карађорђевог опраштања од Србије, поред цара Московског, споменуо још један инострани град, додуше из Бугарске. Вожд намерава да устаницима набави олово, барут и: „Из Силистре оштрога кремена" (Караџић 1986а: 40). ${ }^{23}$

Међу мотивским муслиманским песмама среће се и ојконим Пожун. Када хришћански гуслари спомињу Пожуј или Пожун, данашњу Братиславу, опевани су нпр. турска војевања на Беч и судбина српског патријарха Арсенија Чарнојевића (Караџић 1974: 3: 70, 71; Detelić 2007: 67). Епитет бели учестало се везује за више градова (Detelić, Ilić 2006). Али по атрибуцији се издваја - златни Праг, додуше, само у два записа, вероватно ауторског порекла (Detelić 2007: 341).

Од хидронима је река Дунав веома заступљена у традицији Срба и других Словена. Осим ознаке реалија, овај појам је добио и сложенија симболична значења (Jagić 1876), и то не само као део епске локализације радње. Често се лирске слике, поређења и теме везују за тихи Дунав, било да се сугеришу опасности, искушавања љубави, срећни или трагични сусрети младих. ${ }^{24}$ Из обрада тема које се односе на словенске народе махом изостају називи чак и највећих река са словенских простора. Када се са тим упореди учестало лоцирање епске радње у песмама о јунацима и дохађајима од националног значаја, ${ }^{25}$ још је изразитија разлика између аутентичних усмених варијаната и ауторских текстова. Спомињање реке Прут у Његошевој песми још јасније раздваја типове стварања и извора епских хроника.

\section{Словенски род и племе}

С краја 18. и почетка 19. века панславистички покрет повезао је идеологију, политику и културу, у циљу очувања етно-културног идентитета. Заговорници таквих тежњи били су најугледнији појединци из словенских центара. ${ }^{26}$ Али, и много пре ове утопије, међу образованим људима, независно од конфесионалне припадности,

\footnotetext{
${ }^{23}$ У Вуковом Рјечнику стих гласи другачије: И Силистре оштрога кремења, а тумачење се односи на бугарски град. Вероватно је на основу репертоара сељака из Рудничке нахије тај појам унет међу одреднице другог издања Српског рјечника, јер 1818. изостаје из Вуковог корпуса (Караџић 1966; Караџић 1986б: 927). Ипак, за разлику од сабље димискије или стреле татаранке, силистарски кремен не може се придружити фонду формула, карактеристичним за епске стилизације.

${ }^{24}$ По Јагићевом мишљењу у словенском фолклору Дунав има и „,napola mitski sjaj”:

„Čim naime treba da bude govora o nekoj velikoj, širokoj, strašnoj, silnoj rijeci, koja donosi sreću, a još više nesreću, može se već unaprijed pogoditi da će biti spomenut Dunaj-Dunav". Јагић сматра да се симболика Дунава развила у далекој прошлости: „Jer, kad se o tihom Dunaju pjeva daleko na severu na Onješkom jezeru isto tako kao i na jugu, na Ohridskom - onda to podudaranje predstavlja vrlo stara vremena" (Jagić 1876: 153, 150, 174).

25 Лаб и Ситница, Бојана, Морава, Морача, Дрина, Неретва, Сава или свадба Дунава и Саве, у којој притоке добијају улоге уобичајене за свадбени ритуал (Геземан 1925: 12²).

${ }^{26}$ Јан Херкел, Јурај Крижанић, Павел Јозеф Шафарик, Јан Колар, Људевит Гај, Вук Караџић, Енциклопедија бриртаника 2005: 149.
} 
уочава се потреба свеобухватног сагледавања словенских народа. На самом почетку 17. столећа Мавро Орбин штампа Краљевство Словена. ${ }^{27}$

Инспирисан и Орбиновим делом, фрањевац Андрија Качић Миошић је писао песме по узору на усмену епику и објединио их под насловом Разговор угодни народа словинскога $\left(1756,1759^{2}\right){ }^{28} \mathrm{O}$ популарности песмарице сведочи и чињеница да је од 1756. до 1836. доживела десет издања. И за младог Вука је Качићево дело представљало најпре збирку народне поезије. Но, већ 1823. Вук одређује природу тих песама, које су само „налик на народне” (Караџић 1975: 569). По речима С. Милутиновића, Качић је „први славено сербски сабиратељ” (Милутиновић 1990: 38).

Ипак Качићева песмарица није проширила идеје јужнословенског и свесловенског јединства. Снажније су се испољиле романтичарске идеје о духу народа, што је очито при осврту на збирке српских, хрватских, бугарских, муслиманских народних умотворина. Ауторске творевине „на народну” писане током 19. века једним делом испољавају усхићеност Русијом, од које се очекивао „спас за српски народ на Балкану" (Килибарда 1989: 5). Те су тенденције дошле до изражаја у Црној Гори и Босни и Херцеговини након анексије, наравно међу образованим православцима. Занимљиво је и то што су при опонашању стила епске народне поезије писци инсистирали на анонимности, посредно сугеришући прихваћеност творевина.

Тај круг епике, упоређен са богатим корпусом аутентичног усменог стваралаштва, показује да су свесловенске идеје, панславизам, па и русофилство примарно елитистичког карактера. Визија заједнице Словена или православних словенских народа припада уским, ученим круговима. С друге стране, руска империја се међу песмама писаним „на народну” глорификује помоћу класичних епских модела: кликовања виле, борбе против Арапина (аждаје), заштита манастира, сновиђења. Најмлађи, хроничарски наноси су изразито ауторски, што откривају и поднаслови песама. ${ }^{29}$ Идеализација (страног) владара остварује се у сижејном контексту, непосредним коментарима и уз истицање угледа српских и црногорских јунака. Они спасавају руско царство или чланове владарске породице, а за узврат стичу захвалност и почасти и моћне заштитнике. Недовољно упућеним слушаоцима „објашњава” се улога руских царева:

„Петар први, император руски”;

„Од нашега цара славенскога/православна” (Петровић 1951: 4º);

„Страшни царе православни [...]

Сви у тебе над имамо

Ко се крсти су три прста" (Караџић 1974/IV: 38).

${ }^{27}$ Књига је објављена 1601. у Пезару. Руско-словенски превод Саве Владиславића, по налогу руског цара Петра I, штампан је 1728. у Петрограду. Користећи разне изворе и усмено преношене песме и предања, Орбин је писао о прошлости: Далмације, Хрватске, Босне, Србије, Рашке и Бугарске. Та историја није одговарала кодексима римске цркве, те се 1603. наша на списку забрањених књига (Самарџија 2012).

${ }^{28}$ У литератури су навођени: три млетачка $(1756,1758,1759)$ или једно будимско (без године) и два млетачка издања $(1756,1759)$. Преовлађује мишљење да је Разговор први пут објављен у Венецији, 1756 , а затим 1759. (Пантић 2002: 202).

${ }^{29}$ Тежња ка историјској тачности испољава се у навођењу датума. Његош у Огледалу српском то чини редовно, независно од тога да ли су опевани догађаји локалног или националног значаја или се односе на везе са Русијом. 
Илузија објективности постиже се указивањем на околности, у којима је Русија принуђена да окрене леђа савезницима и склопи примирје са непријатељима. Још једном треба нагласити да процес прихватања поезије, чији су писци образовани људи, не пружа аргументе теоријама о генези усменог песништва. ${ }^{30}$ Примери „руских тема” у српској усменој традицији боље илуструју обрнут смер утицаја - од усменог фонда ка опонашању епске технике. Ти текстови, у служби ширења одређене идеологије, не могу се придружити „високој” литератури, тим пре што управо по естетским дометима далеко заостају за најбољим усменим варијантама. Епско песништво је било погодно за популаризацију идеолошких и политичких тежњи. Али и пошто су се поједини словенски народи ујединили, распад тих држава крајем 20. века открио је наличје једне утопије и превласт политике над културном баштином.

\section{Извори}

Богишић В. Народне пјесме из старијих највище приморских записа. Биоград: СКА, 1878 - Горњи Милановац: ЛИО, 2003. ${ }^{2}$

Геземан Г. Ерлангенски рукопис старих српскохрватских народних песама. Сремски Карловци: Српска краљевска академија, 1925.

Караџић В. С. Пјеснарища 1814. 1815. СД, І. Пр. В. Недић. 1965.

Караџић В. С. Српски рјечник (1818). Сабрана дела В. С. Караџића (СД), ІІ. Пр. П. Ивић. Београд: Просвета, 1966.

Караџић В. С. Етнографски списи. Пр. М. Филиповић, Г. Добрашиновић. Београд: Просвета. 1969.

Караџић В. С. Српске народне пјесме из необјављених рукописа Вука Стеф. Каpauић, I-IV. Пр. Ж. Младеновић, В. Недић. Београд, САНУ, 1974.

Караџић В. С. Српске народне пјесме I. СД IV, Пр. В. Недић. 1975.

Караџић В. С. Српске народне пјесме IV. СД VII, Пр. Љ. Зуковић. 1986.

Караџић В. С. Српски рјечник (1852). СД ХІ/1, Пр. Ј. Кашић. 1986.

Караџић В. С. Српске народне пјесме II. СД V, Пр. Р. Пешић.1988.

Караџић В. С. Српске народне пјесме III. СД VI, Пр. Р. Самарџић. 1988а.

Милутиновић С. Пјеванија ирногорска и хериеговачка. Лајпциг 1837. Пр. Д. Аранитовић. Никшић: Универзитетска ријеч, 1990.

Недић В. Антологија народних лирских песама. Београд: СКЗ, 1977.

Пантић М. Народне песме у записима 15. до 18. века. Београд: Просвета, 2002.

Петрановић Б. Српске народне пјесме из Босне и Хериеговине, I-III. Пр. Н. Килибарда. Сарајево: Свјетлост, 1989.

Петровић Његош П. Олледало српско. Сабрана дела Петра Петровића Његоша, 5. Пр. Р. Бошковић - В. Латковић. Београд: Просвета: 1951.

Петровић С. Косовска битка у усменој поезији. Београд: Гутенвергова галаксија, 2001.

\footnotetext{
${ }^{30}$ То се посебно односи на приступе Крочеа, Наумана или Мајера (Кokjara 1985/II: 303-306, 320-324).
} 


\section{Лuтература}

Банашевић Н. Белешке и објашњења уз трећу књигу Српских народних пјесама Вука Стеф. Караиића. Београд: Просвета, 1954.

Веселовски А. Историјска поетика. Прев. Р. Мечанин. Београд: Zepter Book World, 2005. / А. Н. Веселовский, историческая поэтика.

Ван Генеп А. Обреди прелаза. Прев. Ј. Лома, прир. А. Лома. Београд: СКЗ, 2005. / Van Genep, A. Les rites de passage. Paris: Emile Nourry, 1909.

Гура А. Симболика животиња у словенској народној традииији., Београд: Бримо - Логос, 2005. / А. В. Гура, Символика животных в славянской традииии. Москва: Индрил, 1997.

Деретић Ј. Српска народна епика. Београд: Филип Вишњић, 2000.

Детелић М. Урок и невеста, поетика епске формуле. Београд: Балканолошки институт САНУ, 1996.

Ђорђевић Белић С. Постфолклорна епска хроника. Жанр на гранищи и границе жанра. Београд: Чигоја штампа, 2016.

Килибарда Н. Богољуб Петрановић као сакупљач народних пјесама. Предговор Б. Петрановић, нав. изд, стр. 1-28.

Костић Д. Тумачења друге књиге Српских народних пјесама Вука Стеф. Караџића. Београд, 1937.

Костић Д. „Два косовска цикла.” Прилози проучавању народне поезије. Београд, књ. VI, св. 1 (1939): стр. 1-18.

Љубинковић Н. Пјеванија ирногорска и хериеговачка Симе Милутиновића Сарајлије. Београд: Рад, КПЗ Србије, 2000.

Матић С. Белешке и објашњења за другу књигу Српских народних пјесама Вука Стеф. Караџића. Београд: Просвета, 1958.

Меденица Р. Наша народна епика и њени твории. Цетиње - Београд: Обод, 1975.

Милошевић-Ђорђевић Н. „Девојка и Шишман: историја и усмена традиција.” Студије и грађа за историју књижевности. Београд: Институт за књижевност и уметност, 1986: стр. 139-148.

Милошевић-Ђорђевић Н. Радост препознавања. Нови Сад: Матица српска, 2011.

Михаљчић Р. Крај српског ирарства. Београд: СКЗ, 1975.

Недић В. Вукови певачи. Пр. Р. Пешић. Нови Сад: Матица српска, 1991.

Орбин М. Краљьевство Словена, Зрењанин: Sezambook, 2006. / M. Orbin. Il regno de gli Slavi hoggi corrottamente detti Schiavoni. Historia, Pesaro: G. Concordi, MDCI.

Пантић М. Мавро Орбин. Предговор: М. Орбин, нав. дело, стр. XI-CXV.

Петковић Д. Типологија епских песама о женидби јунака. Београд: Чигоја штампа, 2008.

Путилов Б. Н. Јуначки еп Црногорача. Прев. Д. Аранитовић. Титоград: Универзитетска ријеч - Побједа, 1985. / Путилов, Б. Н. Героический эпос Черногорцев. Ленинград: Академия наук СССР, 1982.

Самарџија С. Биографије епских јунака. Београд: Друштво за српски језик и књижевност Србије, 2008.

Самарџија С. „Мавро Орбин и краљевство традиције”. Годишъак Катедре за српску књижевност са јужнсловенским књижевностима. Књ. VII. Београд, Филолошки факултет, (2012), стр. 33-65. 
Самарџија C. „Епски јунак у својој и туђој култури.” Делић L. (ur.) Филолошке студије, св. 2 (2014): стр. 430-447.

Толстој Н. И. Језик словенске културе. Пр. Љ. Раденковић. Ниш: Просвета, 1995.

Халанский, М. Южно-славянские сказание о Кралевиче Марко в связи с спроизведениями русского былевого эпоса. Варшава 1893-1896.

Detelić M., Ilić M. Beli grad. Beograd: Balkanološki institut SANU, 2006.

Jagić V. „Dunav - Dunaj u slavenskom narodnom pjesmičtvu.” Archiv für slavisdhe Philologie, Berlin, I (1876): str. 299-333. Prev: Jagić V. Izabrani kraći spisi. Zagreb, 1948, str. 150-177.

Kačić Miošić A. Razgovor ugodni naroda slovinskog. Djela Andrije Kačića Miošića, I. Zagreb: HAZU, 1942.

Kokjara, Đ. Istorija folklora u Evropi, I-II. Prev. T. Majstorović, J. Vučo. Beograd: Prosveta, 1985 / G. Cocchiara. Storia del folklore in Evropa. Torino: Ed. Boringhierti, 1971.

Krstić B. Indeks motiva narodnih pesama balkanskih Slovena. Beograd: SANU, 1984.

Maretić T. Naša narodna epika. Pr. V. Nedić. Beograd: Nolit, 1966.

Meletinski E. M. Poetika mita. Prev. J. Janićijević. Beograd: Nolit, b. g. Pešić R., Milošević-Đorđević N. Narodna književnost. Beograd: Vuk Karadžić, 1984.

Снежана Д. Самарджия

СЛАВЯНСКИЙ МИР В СЕРБСКОМ УСТНОМ НАРОДНОМ ТВОРЧЕСТВЕ

Резюме

Представления о славянских народах по-разному репрезентированы в сербском фольклоре и стилизованы в соответствии с закономерностями эпической поэзии. В данном случае выделяются отдельные персонажи (Шишман/король Шишманин, король Владислав, московские/русские правители), их отношения с героями сербской традиции, а также стилизации интернациональных мотивов. Указано на подходы, в которых прослеживаются возможные отзвуки исторических событий с эпохи средневековья до середины XIX века. Выделены приемы обозначения пространства и символическая роль России как защитницы православия. Такие значения вместе с точной датировкой событий русско-турецких войн встречаются среди эпических песен, которые писали Петр I Петрович и Петр II Петрович Негош, как и в записях Б. Петрановича.

Подчеркнуто, что этот корпус текстов не дает аргументов теориям о генезисе устной народной поэзии. Примеры «русских тем» и славянофильства в сербской устной традиции лучше иллюстрируют подражание эпической технике в целях распространения определенной идеологии.

Ключевые слова: славяне, сербское устное народное творчество, персонажи, формула, пространство. 